\title{
BEHAVIORAL AND ELECTROPHYSIOLOGICAL STUDY OF THERMAL AND MECHANICAL PAIN MODULATION BY TRP CHANNEL AGONISTS
}

\author{
Received December 21, 2012.
}

Transient receptor potential channels (TRP) have been extensively investigated over the past few years. Recent findings in the field of pain have established a family of six thermoTRP channels (TRPA1, TRPM8, TRPV1, TRPV2, TRPV3, and TRPV4) that exhibits sensitivity to increases or decreases in temperature, as well as to chemical substances eliciting the respective hot or cold sensations. Such irritants include menthol, cinnamaldehyde, gingerol, mustard oil, capsaicin, camphor, eugenol, and others. In this study, we used behavioral and electrophysiological methods to investigate if mustard oil (allyl isothiocyanate, AITC) and capsaicin affect the sensitivity to thermal, innocuous cold, and mechanical stimuli in male rats. Unilateral intraplantar injection of AITC and capsaicin induced significant decreases in the latency for ipsilateral paw withdrawal from a noxious heat stimulus, i.e., heat hyperalgesia. These agents also significantly reduced the mechanical withdrawal thresholds of the injected paw, i.e., mechanical allodynia. Bilateral intraplantar injections of AITC resulted in a two-phase effect on cold avoidance (thermal preference test). A low concentration of AITC (5\%) did not change cold avoidance similarly to the vehicle control, while higher AITC concentrations (10 and 15\%) significantly reduced cold avoidance, i.e., induced cold hypoalgesia. Capsaicin acted in almost the same manner. These results indicate that TRPA1 channels are clearly involved in pain reactions, and the TRPA1 agonist AITC enhances the heat pain sensitivity, possibly by indirectly modulating TRPV1 channels, which are co-expressed in nociceptors with TRPA1s. In electrophysiological experiments, neuronal responses to electrical and graded mechanical and noxious thermal stimulations were tested before and after cutaneous application of AITC. Repetitive application of AITC initially increased the firing rate of spinal wide-dynamic range neurons; this was followed by rapid desensitization that persisted when AITC application was reapplied 30 min later. The responses to noxious thermal (but not to mechanical) stimuli were significantly enhanced irrespective of whether the neuron was directly activated by AITC. These findings indicate that AITC produced peripheral sensitization of heat nociceptors. Overall, our data support the role of hermosensitive TRPA1 and TRPV1 channels in pain modulation and show that these thermoTRP channels are promising targets for the development of a new group of analgesic drugs.

Keywords: heat pain, hyperalgesia, mechanical allodynia, mustard oil, capsaicin, nociception, thermal preference.

\section{INTRODUCTION}

Recent findings in the field of pain have established a subset of transient receptor potential (TRP) channels that are activated by temperature (the so-called thermoTRP channels) and are capable of initiating

\footnotetext{
${ }^{1}$ Ivane Beritashvili Experimental Biomedicine Center, Tbilisi, Georgia.

${ }^{2}$ University of California at Davis, Davis, California, USA.

Correspondence should be addressed to M. G. Tsagareli

(e-mail: tsagareli@biphysiol.ge or merab.tsagareli@caucasus.net).
}

sensory nerve impulses in the course of detection of thermal, mechanical, and chemical stimuli [1, 2]. A family of six thermoTRP channels (TRPA1, TRPM8, TRPV1, TRPV2, TRPV3, and TRPV4) exhibits sensitivity to increases or decreases in temperature, as well as to the action of chemical substances eliciting the respective hot or cold sensations. Such irritants include menthol (from mint), cinnamaldehyde, gingerol, capsaicin (from chili peppers), mustard oil, camphor, eugenol (from cloves), and others [2-4]. Our recent studies indicated that unilateral intraplantar 
injection of cinnamaldehyde (CA) induced a significant concentration-dependent reduction in the latency of the ipsilateral paw withdrawal reflex from a noxious heat stimulus. This agent significantly reduced mechanical withdrawal thresholds of the injected paw too. Bilateral intraplantar injections of CA resulted in significant cold hyperalgesia (cold-plate test) and a mild enhancement of innocuous cold avoidance (thermal preference test) [4-6]. Menthol, an agonist of cold-sensitive TRPM8 channels, reduced heat pain and exerted a two-phase effect on cold sensation, reducing cold sensitivity at high concentrations and increasing cold sensitivity at low concentrations $[4,5,7]$.

In this study, we examined whether mustard oil (MO) [allyl isothiocyanate (AITC)] and capsaicin affect sensitivity to thermal and mechanical stimuli in male rats. Isothiocyanate compounds constitute the pungent ingredients in horseradish, onion, wasabi, and other mustard extracts. Topical application of AITC has, for a long time, been known to activate somatosensory neurons, resulting in acute pain and neurogenic inflammation through peripheral release of neuropeptides from the primary afferent nerve terminals. This, in turn, produces robust hypersensitivity to thermal and mechanical stimuli [2]. In the search for the MO receptor, Jordt et al. discovered that a wide range of isothiocyanate compounds activate TRPA1 channels [8,9]. When applied to the skin, AITC elicits burning pain, thermal hyperalgesia, and mechanical allodynia [10]. When acting on the oral or nasal mucosa, AITC causes burning irritation, which decreases (desensitization) across trials of repeated application [11, 12], as well as heat hyperalgesia [13]. Lingual application of AITC excites neurons in the trigeminal subnucleus caudalis (Vc) [14-16]. In addition to a behavioral study, here we tested whether spinal wide-dynamic range (WDR) dorsal horn neuronal responses to repeated cutaneous application of AITC similarly exhibit a desensitizing pattern, and whether their responses to mechanical and noxious thermal stimuli are enhanced after application of this chemical.

The capsaicin TRP channels were the first to be discovered in the mammalian sensory system. Julius, Caterina, et al. [17] used an expression cloning strategy to functionally search for capsaicin receptors. Using this approach, they identified the TRPV1 channel as a capsaicin receptor. Analyses of TRPV1-deficient animals have revealed a key role for TRPV1s in both acute heat detection and thermal hypersensitivity following injury and inflammation $[18,19]$.

In this study, we hypothesize that intraplantar 370 injection of various concentrations of AITC and capsaicin would induce hyper- or hyposensitivity to 30 and $15^{\circ} \mathrm{C}$ temperatures (thermal preference test).

\section{METHODS}

Animals. Behavioral studies using adult male Wistar and Sprague-Dawley rats (350-500 g) were singly housed and given rodent chow and water ad libitum.

Application of Chemicals. AITC at doses of 5, 10 , and $15 \%$, capsaicin at concentrations of $0.1,0.2$ and $0.4 \%$ (Sigma-Aldrich, USA), or vehicle control (mineral oil or Tween 80, Fisher Scientific, USA) were injected intraplantarly using 30 -gauge needles.

Behavioral Tests. For behavioral testing, thermal (Hargreaves method, 390, IITC, USA) and mechanical (Von Frey method, IITC, USA) paw withdrawal tests were carried out using the techniques described previously [5, 7]. After baseline testing, the rat received unilaterally intraplantar injections of AITC, capsaicin, or vehicle, and the withdrawal latencies for both paws were measured at 5, 15, 30, 45, 60, 90, and 120 min post-injection. In the mechanosensitivity tests, we used an electronic von Frey filament (2390, IITC, USA) that was pressed against the ventral paw surface from below, through a mesh stand the animal stood on. The device monitored the force $(\mathrm{g}, \sim 0.01 \mathrm{~N})$ at the moment of initiation of the paw withdrawal reflex.

For thermal preference tests, the rat was placed onto a surface consisting of two adjacent thermoelectric plates (AHP-1200DCP, Teca Thermoelectric, USA) that could be independently heated or cooled to a preset temperature $\left(-5^{\circ} \mathrm{C}\right.$ to $\left.>50^{\circ} \mathrm{C}\right)$. One plate was set at $30^{\circ} \mathrm{C}$, and the other at $15^{\circ} \mathrm{C}$ in a counterbalanced design. AITC, or capsaicin, or vehicle, was bilaterally injected intraplantarly, and the animal was placed onto one of the plates in a matched block design alternating the initial position and temperature.

\section{Electrophysiological Testing}

Surgery. Rats were anesthetized with sodium pentobarbital $(65 \mathrm{mg} / \mathrm{kg}$, i.p.), and supplemented as needed so that a strong tail and paw pinch failed to evoke a withdrawal response. A tracheostomy tube was inserted, the jugular vein was cannulated with PE-50 tubing for the maintenance of pentobarbital anesthesia, and wound clips were used to close the incision. The core body temperature was monitored rectally using a BAT-12 thermometer (Physitemp, USA) and maintained at $37 \pm 0.2^{\circ} \mathrm{C}$ with a heating pad. During

NEUROPHYSIOLOGY / НЕЙРОФИЗИОЛОГИЯ.-2013.—-Т. 45, № 4 
recording, the anesthesia level was maintained by i.v. pump infusion $(10-20 \mathrm{mg} / \mathrm{kg} \cdot \mathrm{h})$ of pentobarbital. The posterior superior iliac spine and a midline skin incision were made from the approximately L6 to T11 spinous processes. The $\mathrm{L} 1$ and $\mathrm{T} 13$ spinous processes were cut and removed, and a bilateral laminectomy was performed at both levels under a dissection microscope with micro-rongeurs. The dura was removed, and warm agar was poured over the spinal cord. Vertebral clamps on the transverse processes of T12 and L2 were used to stabilize the animal in a stereotaxic frame (Kopf Instruments, USA). After placement in the stereotaxic frame, $\mathrm{CO}_{2}$ was monitored by a gas analyzer (DatexOhmeda, USA) and maintained between 3.0 and $4.0 \%$ by adjustment of the tidal volume and/or respiratory rate.

Stimulation and Recording. A Teflon-coated tungsten microelectrode (8-11 M $\Omega$ ) was advanced into the dorsal horn of the spinal cord using a hydraulic microdrive to record single unit activity of dorsal horn neurons. Units isolated for study were always at depths $\sim 1 \mathrm{~mm}$. Action potentials (APs) were amplified and displayed by conventional means and sent to a computer for storage and analysis using a PowerLab interface and Chart 5.0 software (AD Instruments, USA). Only units that responded to graded innocuous (brushing, 4-12 g von Frey) and noxious (76 g von Frey, pinch) mechanical and noxious thermal (42, 46 , and $50^{\circ} \mathrm{C}$ ) stimuli were considered for further study. Ten minutes after completion of the mechanical and thermal stimulation series, 60 -sec-long baseline activity was recorded before application of either AITC or vehicle control (mineral oil). AITC or mineral oil was then topically applied to the center of the plantar receptive field area with 1-min-long intervals for 10 min using a Hamilton microsyringe attached to a PE-50 tubing. Application of AITC was repeated after a 10 -min wait period. Thus, $30 \mathrm{~min}$ had passed between the last AITC application of trial 1 and the first AITC of trial 2. On completion of the experiment, animals were euthanized by an overdose of pentobarbital, i.v.

Data Analysis. The latencies of thermal and mechanical paw withdrawal responses and those in the thermal preference test were normalized with respect to the baseline averages and subjected to oneway repeated-measure analysis of variance (ANOVA) using InStat 3.05 (GraphPad Software Inc., USA). A $95 \%$ confidence interval was used for all statistical comparisons; standard errors of the mean are shown. The spontaneous electrical firing rate was calculated as the sum of the total number of APs generated for 30 or $60 \mathrm{sec}$ before each stimulus. Responses to mechanical and thermal stimuli were quantified by summing the total number of APs recorded during the 10 -sec-long stimulation period and subtracting the spontaneous firing rate per $10 \mathrm{sec}(30 \mathrm{sec}$ total/3). The afterdischarge was quantified as the total number of APs during $30 \mathrm{sec}$ after the offset of the stimulus. Spontaneous firing, evoked responses, and afterdischarges to each mechanical and thermal stimulus were compared pre- $v s$ post-treatment for each treated group (AITC and mineral oil) using the paired $t$-test. Responses to AITC and mineral oil were quantified by summing the total spiking during a 60 -sec-long interval after each application. Each sum was compared with the sum of APs during $60 \mathrm{sec}$ preceding the first application (baseline) using univariate ANOVA with the post-hoc Dunnett's two-sided $t$-test. A $P$ value of $<0.05$ was taken to be significant. Statistical analyses were performed using SPSS 9.0 software.

\section{RESULTS}

\section{Behavioral Data AITC Application}

Thermal (Hargreaves) Paw Withdrawal Test. Application of AITC resulted in a significant dosedependent reduction in the ipsilateral thermal paw withdrawal latency. Figure $1 \mathrm{~A}$ shows the mean withdrawal latencies of the injected paw $v s$ time relative to injection of vehicle or AITC at each concentration tested. There was a dose-dependent reduction in the latency, with the $15 \%$ AITC concentration significantly different from vehicle and 5\% AITC treatments. The highest dose resulted in a mean reduction to $73.7 \%$ of the pre-injection baseline value by $30 \mathrm{~min}$ with partial recovery at $120 \mathrm{~min}$. For the contralateral paw (B), there was an overall significant effect of treatment, with the $15 \%$ group being significantly different from saline.

Mechanical (von Frey) Paw Withdrawal Test. Mechanically evoked withdrawal thresholds are plotted $v s$ time for the treated paw in Fig. 1C. At each AITC concentration, the thresholds were significantly different from those at vehicle, but not from each other. The mean withdrawal thresholds for the contralateral paw (D) were not affected significantly at any AITC concentration.

Two-Temperature Preference Test. On $30^{\circ} \mathrm{C} v s$ $15^{\circ} \mathrm{C}$ plates, rats treated with higher (10 and 15\%) 
$A$

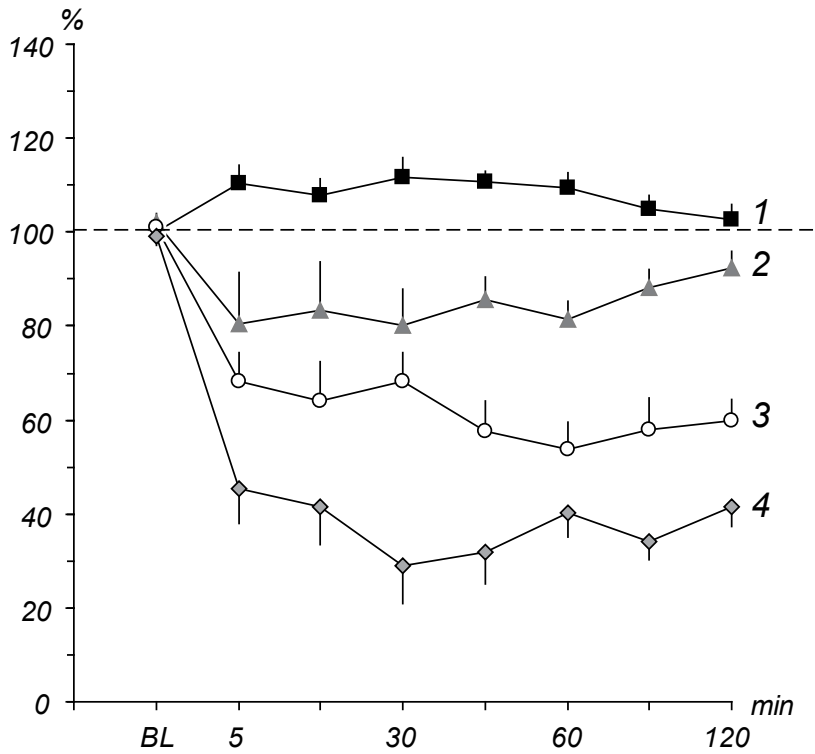

C

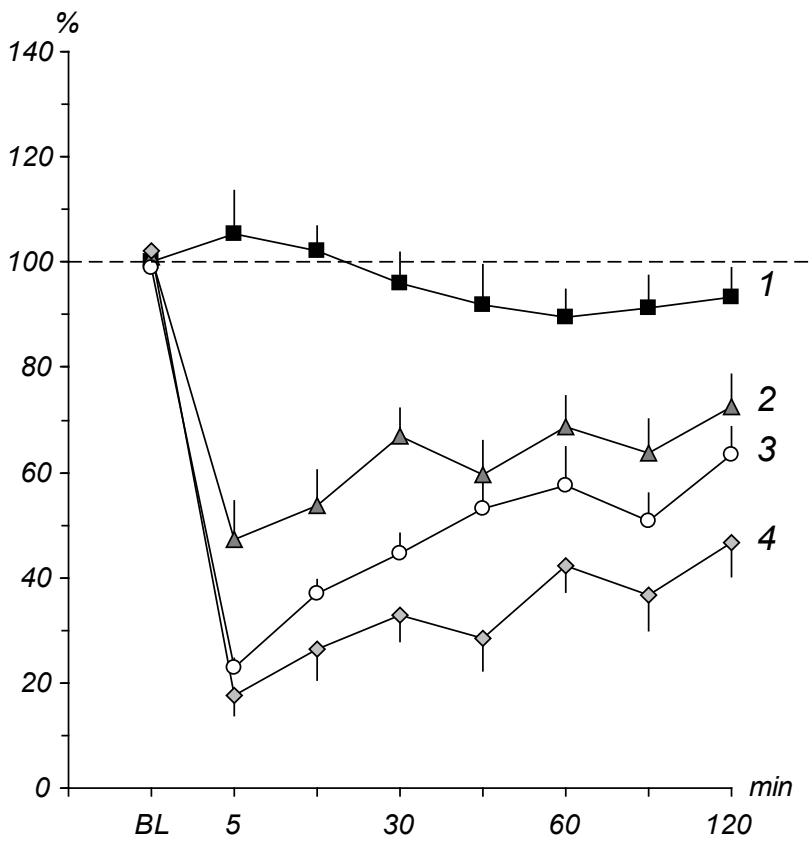

$B$

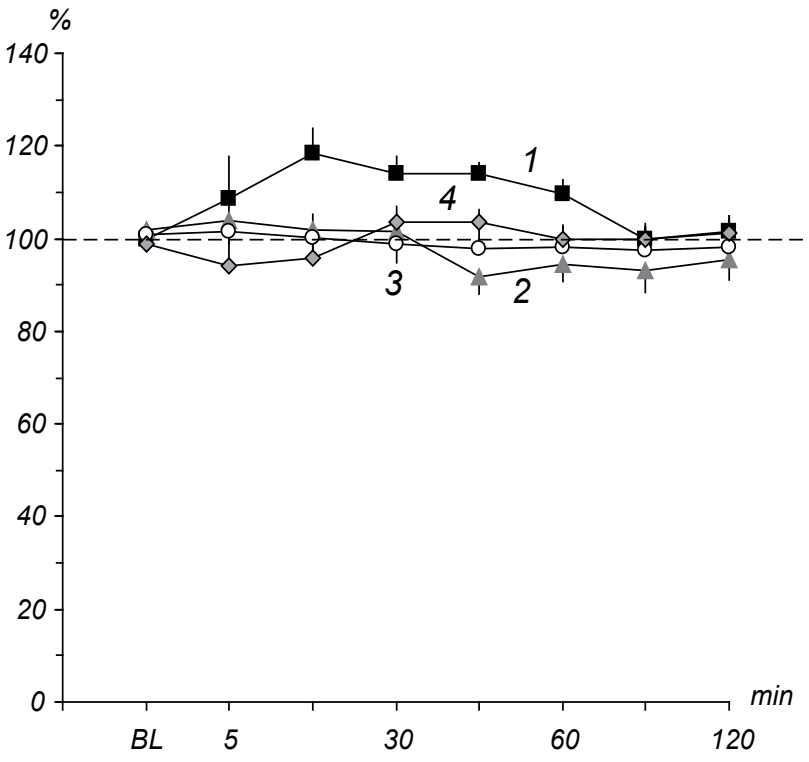

$D$

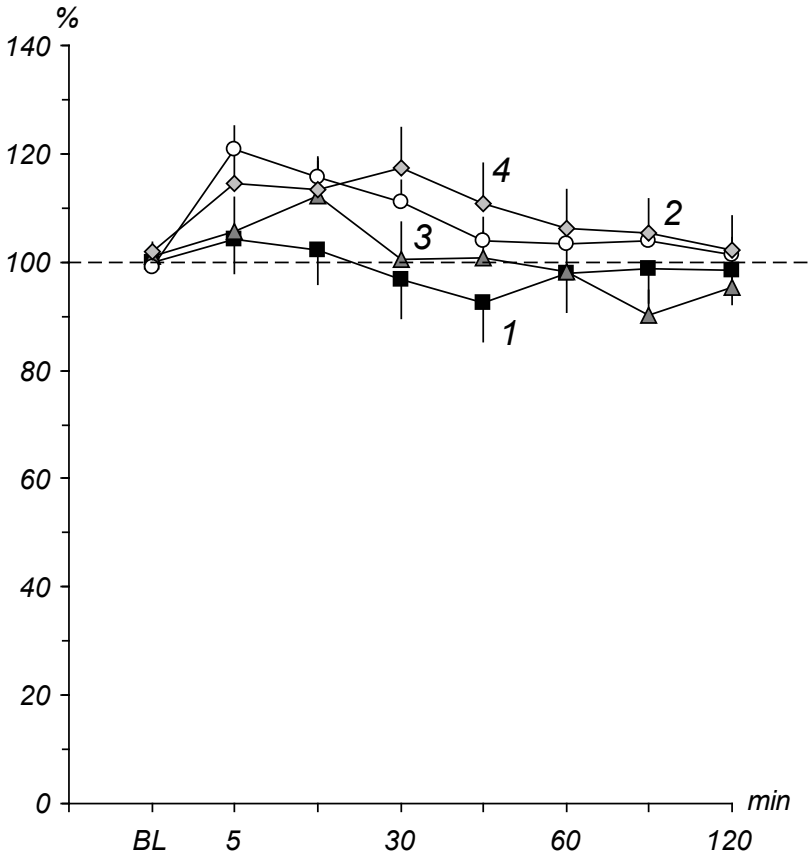

F i g. 1. Dynamics of the normalized thermal paw withdrawal latency (\%) $v s$ time (min). A) Following ipsilateral intraplantar injection of vehicle (control, 1) and allyl isothiocyanate (AITC) at each concentration used (1-3, respectively, 5, 10, and 15\% mustard oil, MO). There were significant effects in AITC groups $v s$ the vehicle group $(P<0.001)$. B) The same as in A but for the contralateral to AITC injection paw. There were no significant effects of any AITC concentration $v s$ the vehicle group. C) The same as in A for von Frey mechanically evoked withdrawal of the injected paw. There were significant effects of all AITC concentrations $v s$ the vehicle group $(P<0.001)$. D) The same as in $\mathrm{C}$ but for the contralateral paw without significant effects of any AITC concentrations. BL) Pre-injection baseline.

Р и с. 1. Залежність нормованих латентних періодів відсмикування кінцівки при тепловій стимуляції (\%) від часу (хв). 


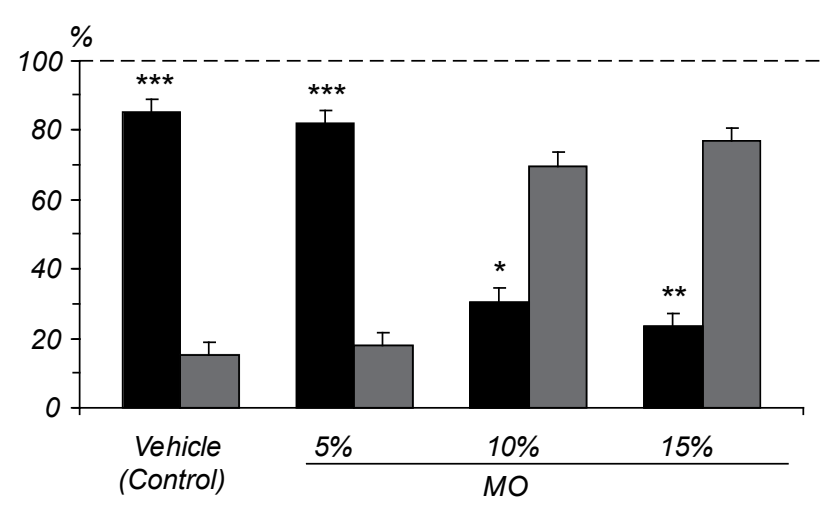

F i g. 2. Biphasic effects of AITC on thermal preference (rats stood on the $30^{\circ} \mathrm{C} v s 15^{\circ} \mathrm{C}$ plate). At high $(10$ and $15 \%)$ AITC concentrations, rats spent significantly more time on the $15^{\circ} \mathrm{C}$ plate (gray bars) compared to the $30^{\circ} \mathrm{C}$ plate (filled bars) $(P<0.05$ and $P<0.01$, respectively), indicating cold hyposensitivity. At the lower (5\%, and vehicle) concentration, rats spent significantly more time on the $30^{\circ} \mathrm{C}$ plate $(P<0.001)$, indicating cold hypersensitivity. Vertical scale) Time spent on the $30^{\circ} \mathrm{C}$ plate, $\%$. MO) Mustard oil.

Р и с. 2. Двофазний вплив алілу ізотіоціанату на термальну преференцію (щури стояли на пластинках при різних температурах, $30^{\circ}$ проти $15^{\circ} \mathrm{C}$ ).

concentrations of AITC exhibited a significant preference for the colder $15^{\circ} \mathrm{C}$ plate compared to the values at vehicle- and $5 \%$ concentration-treated rats (Fig. 2), i.e., the animals significantly avoided the warmer $30^{\circ} \mathrm{C}$ plate.

\section{Capsaicin Application}

Thermal (Hargreaves) Paw Withdrawal Test. The hind-paw injected capsaicin provided a concentrationdependent decrease in the withdrawal latency (Fig. 3A). The $0.1,0.2,0.3$, and $0.4 \%$ capsaicin-treated groups were significantly different from the vehicle group $(P<0.001)$ but not from each other. There was some mirror-image effect for the contralateral hindpaw without significant differences for all concentrations but significantly different from the vehicle group $(P<0.01 ; \mathrm{B})$.

Mechanical (von Frey) Paw Withdrawal Test. For the ipsilateral (treated) hindpaw, the 0.1-0.4\% capsaicin groups were significantly different from the vehicle group (indicating allodynia, Fig. 3C) but not from each other. For the contralateral hindpaw, there were some mirror-image effects, especially for the $0.4 \%$ capsaicin concentration $(P<0.01 ; \mathrm{D})$.

Two-Temperature Preference Test. On $30^{\circ} \mathrm{C} v s$ $15^{\circ} \mathrm{C}$ plates, rats treated with a relatively high $(0.3 \%)$ concentration exhibited significant preference for the colder $\left(15^{\circ} \mathrm{C}\right)$ plate compared to vehicle-treated rats $(P<0.001)$, i.e., the animals significantly avoided the warmer $30^{\circ} \mathrm{C}$ plate (Fig. 4). Another group of rats treated with the highest $(0.4 \%)$ concentration demonstrated an opposite effect, a significant preference for the warmer $\left(30^{\circ} \mathrm{C}\right)$ plate $(P<0.001)$. Two groups of rats treated with lower $(0.1$ and $0.2 \%)$ concentrations of capsaicin exhibited no significant preference for the warmer or colder plates, though the lowest $(0.1 \%)$ concentration-treated rats had a strong preference for the colder $\left(15^{\circ} \mathrm{C}\right)$ plate compared to vehicle-treated rats (Fig. 4).

Electrophysiological Data. Figure 5 shows an example of WDR neuronal responses to AITC applications and to thermal and mechanical stimulation. Buildup of firing to the initial AITC stimuli is shown in Fig. 5G. All WDR neuronal units were also tested for responses to graded (46 and $50^{\circ} \mathrm{C}$ ) heat before and after AITC. Figure 5 shows responses of a unit before AITC (B and $\mathrm{C}$ ) and their clearly visible post-AITC enhancement ( $\mathrm{H}$ and I). The WDR units typically exhibited graded responses to increasing bending forces of the punctuate von Frey stimuli (D-F), which were minimally affected postAITC (J-L).

Figure 6 shows the average responses of WDR units excited by repeated application of AITC (Fig. 6, left, filled peristimulus time histograms, PSTHs) and the responses unaffected by AITC (gray PSTHs). For the responsive units, the mean firing rate during the first three stimulus applications was significantly greater compared to that within pre-AITC baseline. This index, however, declined to a level that was not significantly different from the baseline (Fig. 6, left). After a 30-min-long resting period, AITC application was repeated in the same manner. Although there was a trend toward increase in the firing rate, this effect did not reach statistical significance relative to the pre-AITC baseline (Fig. 6, right) and, in any case, was lower compared with that in the first trial.

\section{DISCUSSION}

The data presented above provide a comprehensive view of the effects of intraplantar injections of AITC and capsaicin on the thermal and mechanical sensitivity. These influences induced a dose-dependent heat hyperalgesia and mechanical allodynia lasting more than $2 \mathrm{~h}$. The AITC-induced enhancement of heat sensitivity is consistent with findings of our 
$A$

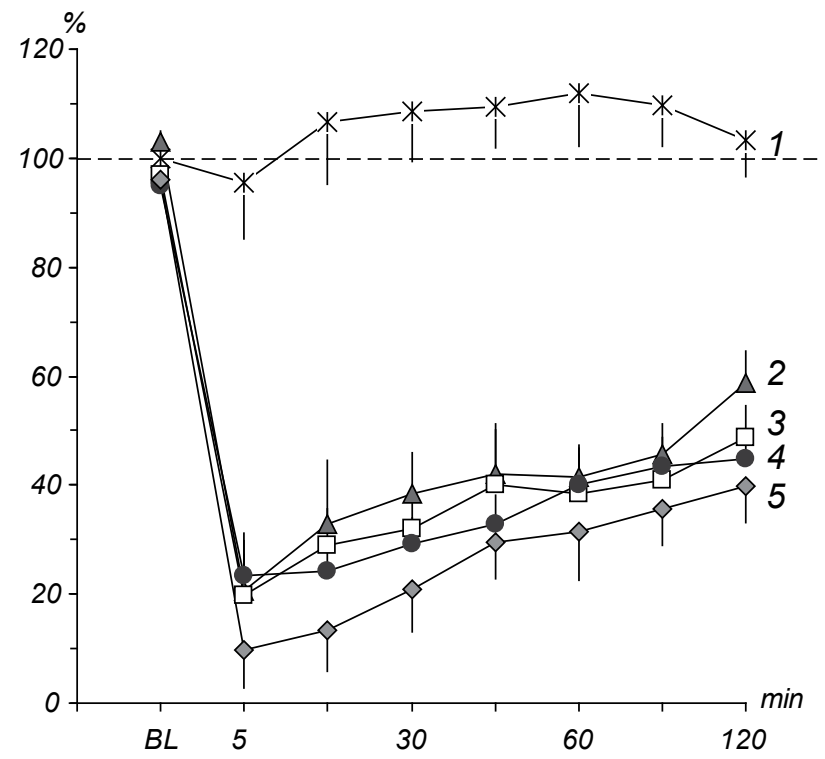

C

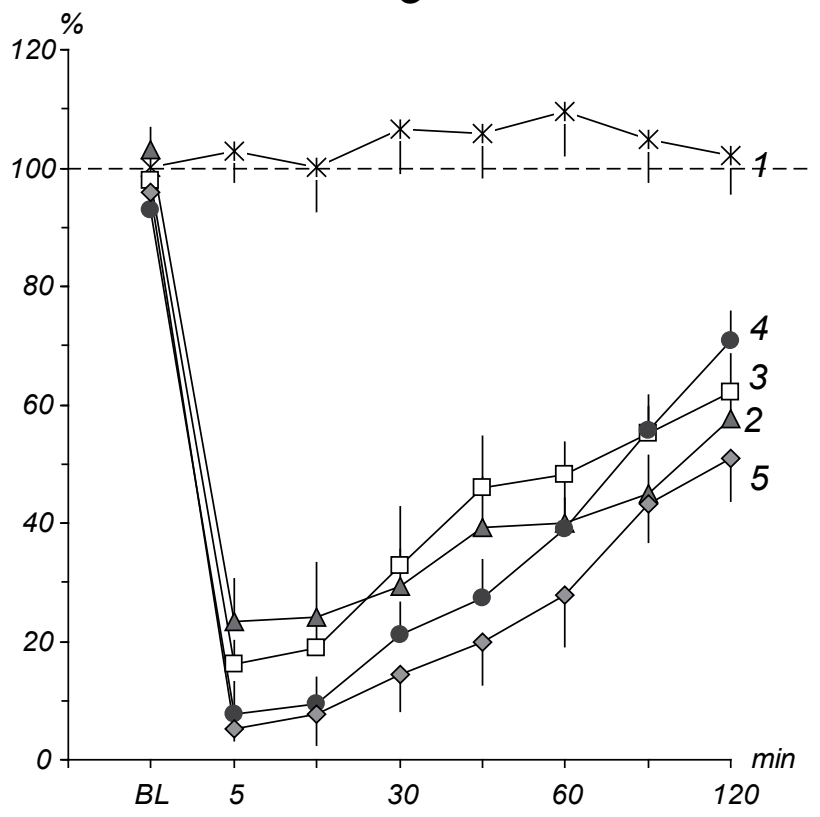

$B$

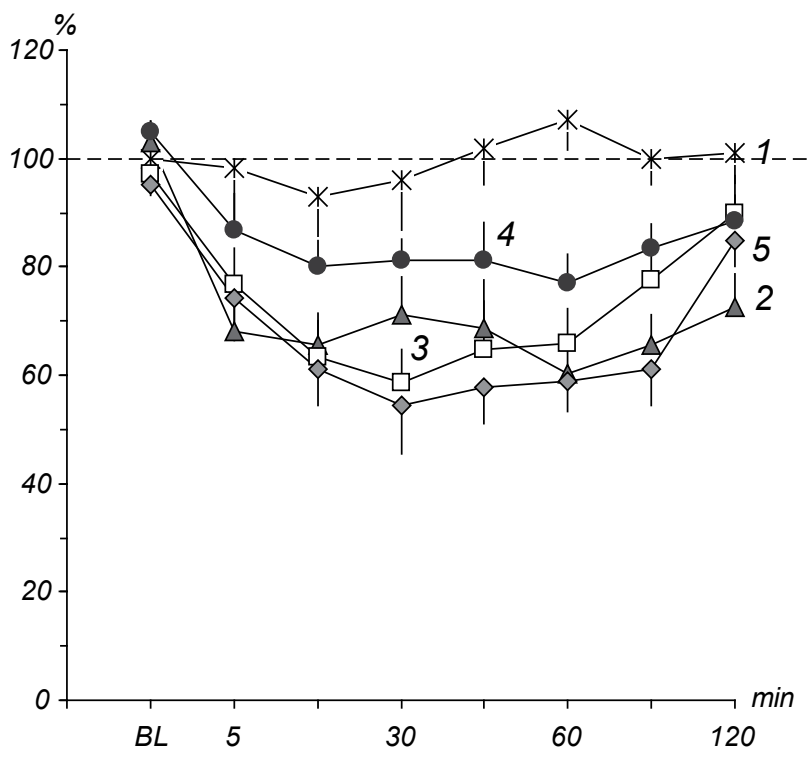

$D$

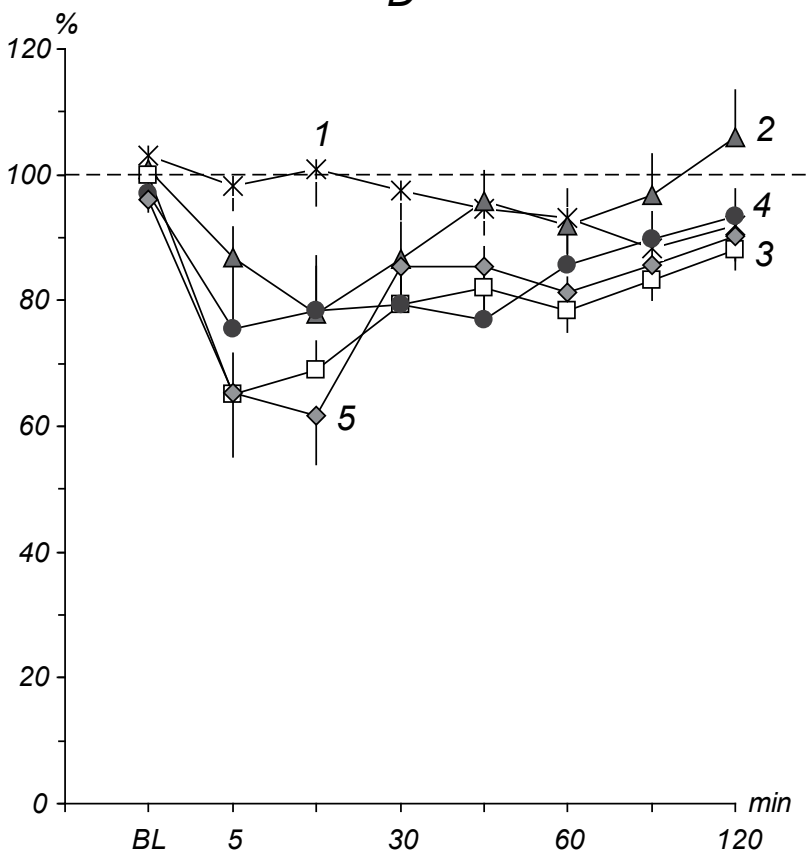

F i g. 3. Dynamics of the normalized thermal paw withdrawal latency (\%) $v s$ time (min). A) Following ipsilateral intraplantar injection of vehicle (control, 1$)$ and capsaicin at each concentration used $(0.1,0.2,0.3$, and $0.4 \%$, respectively $2-5)$. There were significant effect in capsaicin groups $v s$ the vehicle group $(P<0.001)$. B) The same as in A but for the paw contralateral to capsaicin injection. C) The same as in A for von Frey mechanically evoked withdrawal of the injected paw. There were significant effects of all capsaicin concentrations $v s$ vehicle $(P<0.001)$. D) The same as in $\mathrm{C}$ for the contralateral paw. Note that there are some mirror effects of capsaicin injections in the thermal $(\mathrm{B})$ and mechanical withdrawal (D) tests $(P<0.01)$. BL) Pre-injection baseline.

Р и с. 3. Залежність нормованих латентних періодів відсмикування кінцівки при тепловій стимуляції (\%) від часу (хв). 


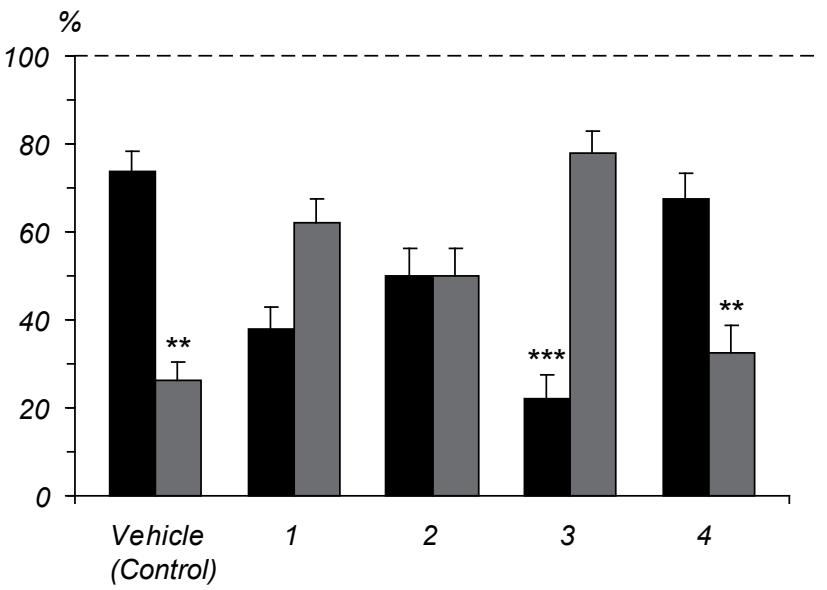

F i g. 4. Biphasic effects of capsaicin (1-4, respectively, 0.1, 0.2, 0.3 , and $0.4 \%$ ) on thermal preference (rats stood on the $30^{\circ} \mathrm{C} v \mathrm{~s}$ $15^{\circ} \mathrm{C}$ plate). At the realitively high $(0.3 \%)$ capsaicin concentration, rats spent significantly more time on the $15^{\circ} \mathrm{C}$ plate (gray bars) compared to the $30^{\circ} \mathrm{C}$ plate (filled bar) $(P<0.001)$, indicating cold hyposensitivity. However, at the highest $(0.4 \%)$ capsaicin concentration, rats spent significantly more time on the $30^{\circ} \mathrm{C}$ plate (filled bar) compared to the $15^{\circ} \mathrm{C}$ plate (gray bar) $(P<0.01)$, indicating cold hypersensitivity. At a lower $(0.2 \%)$ concentration, there was no significant difference between the warm $\left(30^{\circ} \mathrm{C}\right.$, filled bar) and cold $\left(15^{\circ} \mathrm{C}\right.$, gray bar) plates. Vertical scale) Time spent on the $30^{\circ} \mathrm{C}$ plate, $\%$.

Р и с. 4. Двофазний вплив капсаїцину (1-4 відповідно, 0.1, $0.2,0.3$ і $0.4 \%$ ) на термальну преференцію (щури стояли на пластинках при різних температурах, $30^{\circ}$ проти $15^{\circ} \mathrm{C}$ ).

previous studies with CA injections in rats [4-6] and applications of this agent in human subjects [10]. Other investigators found that topical application of AITC produces neurogenic inflammation and, concurrently, heat and mechanical hyperalgesia, presumably via a centrally mediated sensitization process, and that these effects are TRPA1-mediated [3, 8, 9, 20-23].

Dose-dependent increases in the magnitude and duration of heat hyperalgesia induced by AITC and CA were similar to that induced by intraplantar capsaicin herein. Since TRPA1s are co-expressed in sensory neurons expressing TRPV1s [24], heat hyperalgesia induced by AITC and CA might involve activation of these receptors (sensory intradermal terminals of nociceptor nerve endings) in an intracellular mechanism leading to enhanced heat sensitivity of TRPV1s. Alternatively, AITC and CA may cause intradermal release of inflammatory mediators, which lower the heat threshold of TRPV1s [7, 18]. Capsaicin in higher concentrations may also trigger central sensitization, leading to the observed reduction in the withdrawal latency for the contralateral paw
(Fig. 3B, D).

Long-lasting enhancement of mechanosensitivity (i.e., allodynia) following AITC and capsaicin applications (Figs. 1C and 3C) is consistent with previous studies that showed a prolonged decrease in the mechanical withdrawal threshold in mice following intraplantar injection of a TRPA1 agonist, bradykinin $[25,26]$, and with allodynia induced in the human skin by topical application of AITC [13]. The role of TRPA1s in mechanical allodynia is further supported by reports that a TRPA1 antagonist, 4-hydroxynonenal, attenuated inflammation- or nerve injury-induced decreases in the mechanical paw withdrawal thresholds and decreased mechanically evoked responses in $\mathrm{C}$ fibers in mice [27]. In addition, AITC and CA were shown to induce mechanical allodynia in humans [28]. However, TRPA1 as a ligand-gated ion channel in sensory neurons was initially reported to be activated by cold temperatures (below $18^{\circ} \mathrm{C}$ ) $[10,13,19]$, although this opinion has been disputed [3,9]. TRPA1 knockout mice exhibited either normal cold sensitivity [3], or mild [13], or severe deficits [10]. Just recently, Pertovaara et al. [29] showed that TRPA1 channels in the skin contribute to sustained, as well as to noxious mechanical stimulus-evoked, postoperative pain, while spinal TRPA1 channels contribute predominantly to innocuous mechanical stimulus-evoked postoperative pain [30]. Furthermore, spinal TRPA1s are responsible for central pain hypersensitivity under various pathophysiological conditions, such as inflammatory and neuropathic pain [30-33].

However, our previous behavioral data support the role of TRPA1s in cold detection, since intraplantar injection of CA in rats resulted in enhanced avoidance from a cold surface (temperature preference test) and significantly lowered the withdrawal threshold in $0^{\circ} \mathrm{C}$ and $+5^{\circ} \mathrm{C}$ (cold-plate test), phenomena indicative of cold hyperalgesia $[4,5,7]$. These results are consistent with the possibility that TRPA1 agonists can enhance cold-evoked gating of TRPA1 channels to increase their cold sensitivity [34, 35].

Concerning capsaicin-induced effects in previous human experiments, applications of capsaicin on the tongue significantly enhanced heat pain but not cold pain [13]. This finding is consistent with prior psychophysical studies showing that intradermal capsaicin enhanced the heat pain intensity within a small region around the injection site for up to $2 \mathrm{~h}$ [36-38]. The TRPV1 channels sensitive to capsaicin respond to temperatures above the pain threshold [19]. The results presented, might thus be explained 
A
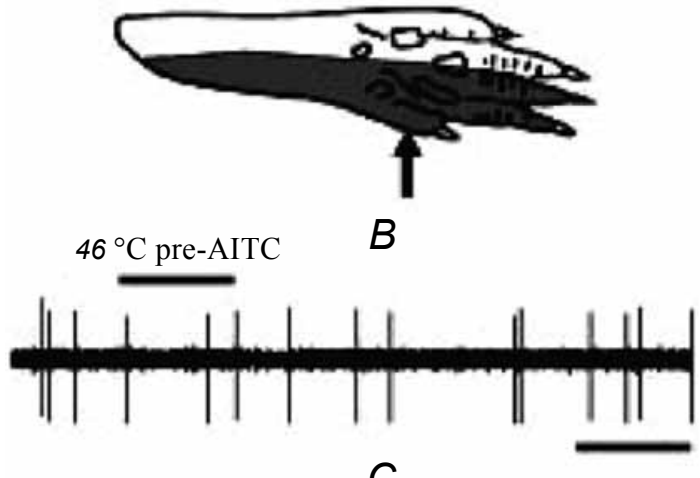

C

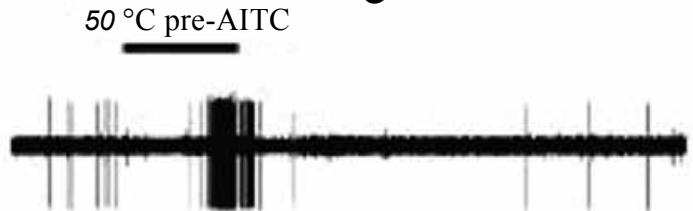

D

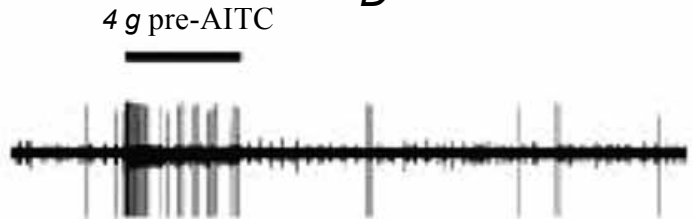

E
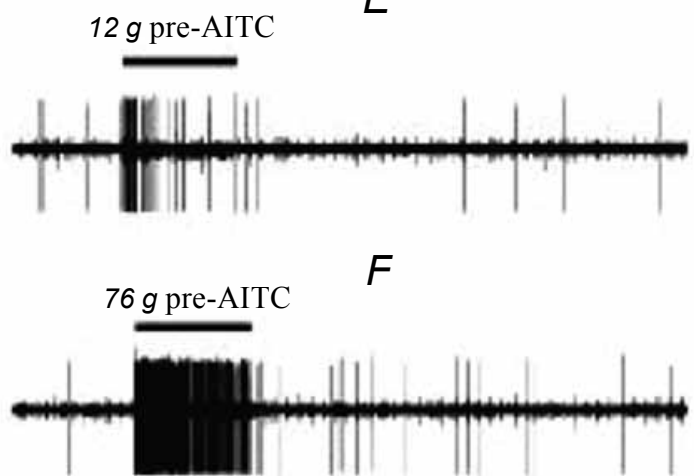

G
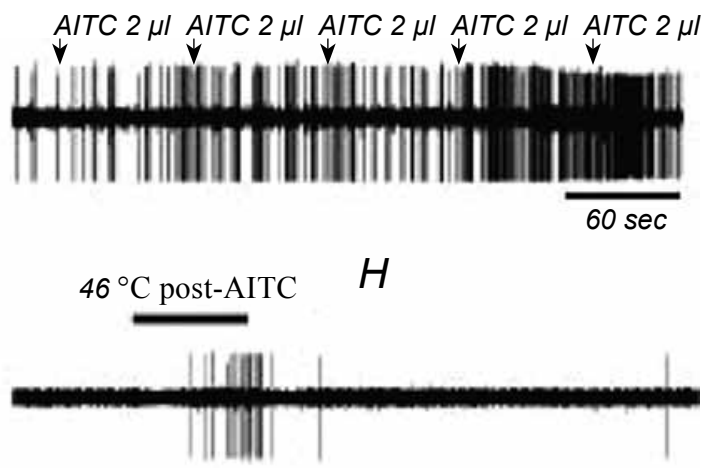

I
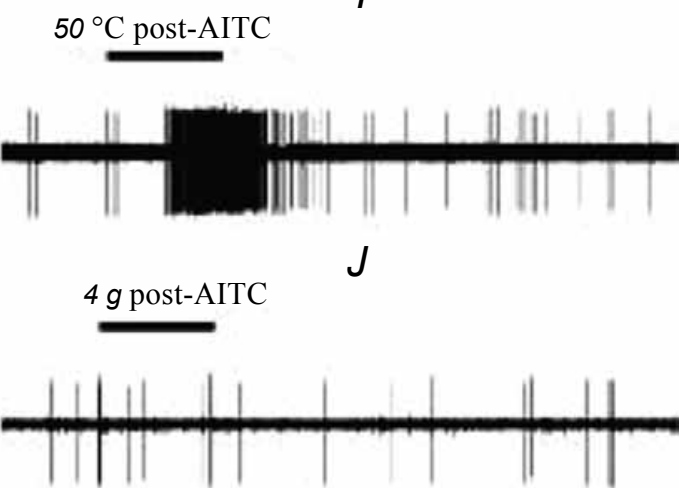

K
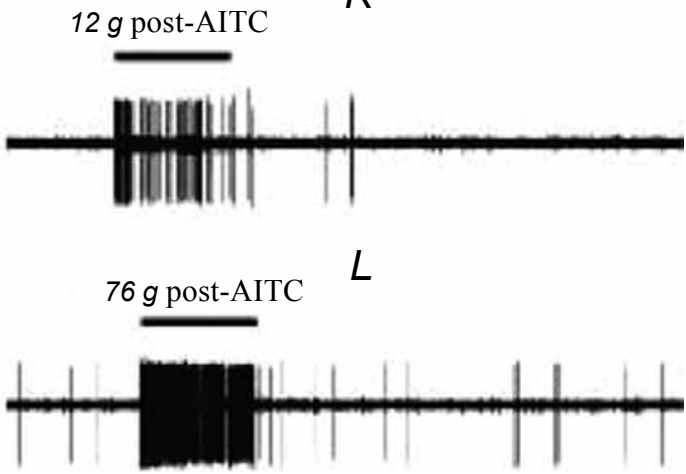

F i g. 5. Example of an AITC-sensitive lumbar spinal wide-dynamic range (WDR) neuron. A) Shaded area shows extent of the mechanosensitive receptive field on the lateral hindpaw. Arrow indicates the site of AITC application. B and C) Raw spike traces of responses to 46 and $50^{\circ} \mathrm{C}$ heat stimuli before AITC application. D-F) Responses to graded mechanical stimulation at indicated von Frey bending forces. G) Spike trace of activity during repeated applications of AITC at 1-min-long intervals (arrows). Note progressive increase in firing rate with desensitization after the 5th stimulus. H-L) Spike traces of responses to graded noxious heat (H, I) and mechanical stimulation (J-L) after sequential application of AITC. Note increased responses to heat but not to mechanical stimulation.

Р и с. 5. Приклад активності люмбального спінального нейрона з великим динамічним діапазоном, чутливого до алілу ізотіоціанату.

by a capsaicin-induced enhancement of thermal gating of TRPV1s expressed in polymodal nociceptors mediating thermal pain sensation $[13,39]$.

A main finding of our electrophysiological study is that AITC sensitizes dorsal horn wide-dynamic range (WDR) neuronal responses to noxious heat, while not significantly affecting responses of these units to mechanical stimuli. This heat sensitization 


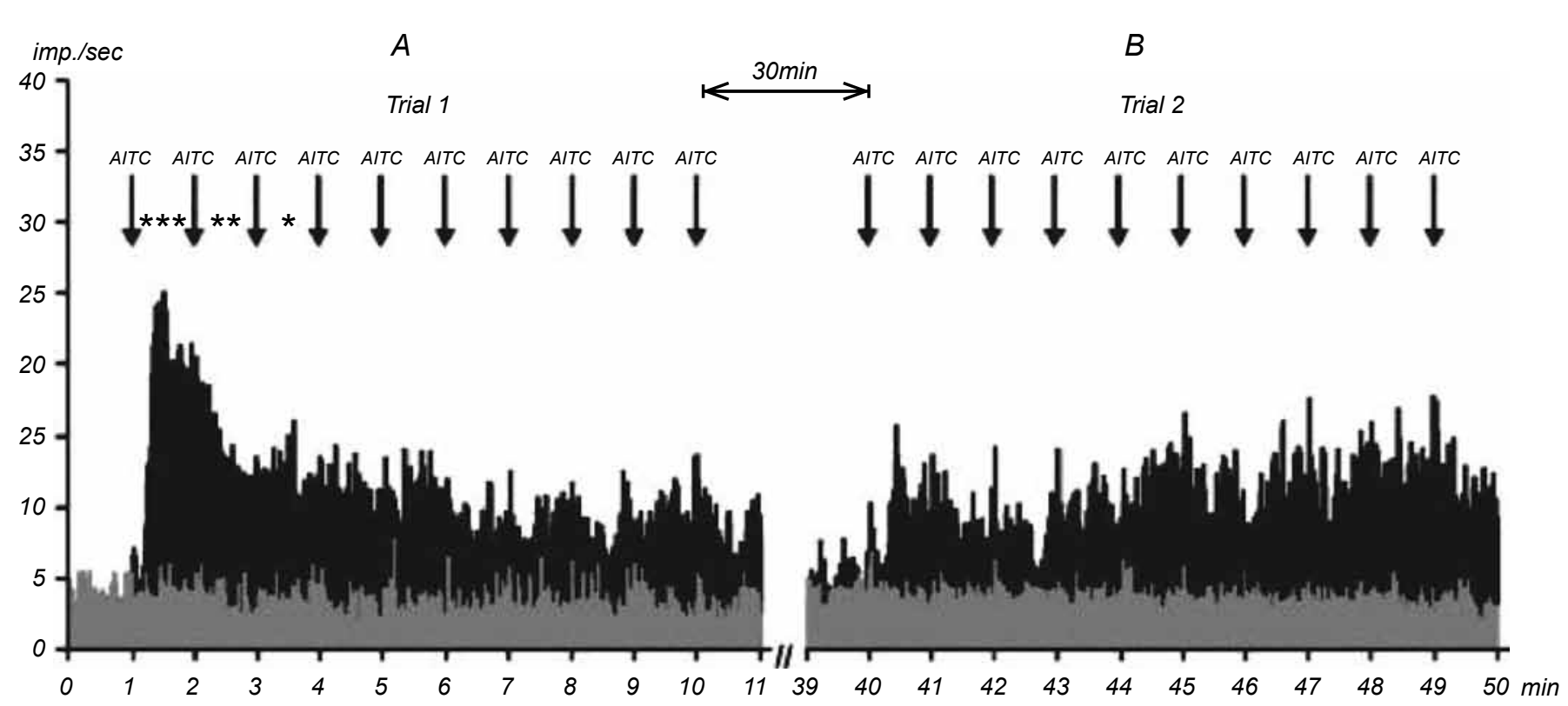

F i g. 6. Desensitization of responses to repeated application of AITC. Shown are averaged peristimulus time histograms (PSTHs, 1-sec bin width) of unit firing during repeated applications of AITC at 1-min-long intervals (arrows) for 10 min to the center of the receptive field area on the ipsilateral hindpaw. Filled PSTHs) 14 WDR units that exhibited increased firing during the initial application of AITC. Gray PSTHs) 13 units unresponsive to AITC. Error bars are omitted for clarity. PSTHs in A) Responses to the first trial of sequential AITC application. PSTHs in B) Responses to second trial of sequential AITC application starting 30 min after the end of the first trial. One, two, and three asterisks indicate significant differences compared with the initial 60 -sec-long baseline period before the first application of AITC $(P<0.05, P<0.01, P<0.001$, respectively).

P и с. 6. Десенситизація відповідей на повторну аплікацію алілу ізотіоціанату.

was observed irrespective of whether AITC directly excited the neuron. The desensitizing response pattern observed presently was similar to that of responses of neurons in trigeminal subnucleus caudalis (Vc) to lingual application of AITC [15, 16], as well as to a desensitizing temporal pattern of irritancy ratings elicited by lingual AITC in humans [12]. On reapplication, AITC evoked no significant increase in WDR neuronal firing, which is consistent with the self-desensitization reported for AITC irritancy on the tongue that lasts less than $10 \mathrm{~min}$ in humans [12].

The mechanism underlying AITC selfdesensitization could involve a peripheral or central site of action. Peripherally, repeated application of AITC may lead to desensitization of TRPA1s expressed in nociceptive endings. AITC-related selfdesensitization was recently reported to occur via a calcium- and calcineurin-independent mechanism in an in vitro assay of peptide release from skin-nerve biopsies [40]. Alternatively (or in addition), central inhibition might contribute to the reduced response of WDR neurons to repeated application of AITC. This is supported by the previous observation that a windup elicited by electrical stimulation of the sciatic nerve significantly attenuated post-AITC. However, such a central inhibitory effect proposed was insufficient to prevent AITC and CA-related enhancements of WDR neuronal responses to noxious heat [41]. Thus, these results strongly indicate that AITC produces peripheral sensitization of heat nociceptors and/or central sensitization at both behavioral and neuronal levels.

Thus, our findings indicate that thermosensitive ion channels are capable of signaling temperature changes across the range normally encountered in the environment. We have a particular interest in the ability of TRP channel agonists to modulate the temperature sensitivity with important ramifications for pain sensation. The TRPV1, being heat sensors, respond to their agonist capsaicin, which elicits corresponding heating sensations. Capsaicin is known to lower the threshold and enhance heat-evoked gating of TRPV1s. The TRPA1 is an exception, since when it is stimulated by various agonists (e.g., MO, CA, etc.), the resultant sensation is one of burning pain rather than of cold. 
However, the role of TRPA1s in cold reception and cold pain sensitivity remains controversial. Our recent data support the role of TRPA1 in cold detection, as the TRPA 1 agonist CA enhanced cold sensitivity in two behavioral assays. The TRPA1 is, no doubt, involved in pain, and TRPA1 agonists enhance the heat pain sensitivity, possibly by indirectly modulating TRPV1s, which are co-expressed with TRPA1s in nociceptors. The thermosensitive TRP channels thus represent an important set of new targets for the development of analgesic drugs.

The Beritashvili EBMC and UC Davis Animal Care and Use Committees approved the study protocols.

The authors, M. G. Tsagareli, I. R. Nozadze, G. P. Gurtskaia, M. I. Carstens, N. J. Tsiklauri, and E. E. Carstens, proclame that they have no conflict of interests.

The work was supported by the grant from Shota Rustaveli National Science Foundation of Georgia (\#1-6/27) and National Institute of Health (DEO13685).

М. Г. Цагарелі, I. Р. Нозадзе ${ }^{l}$, Г. П. Гурикая ${ }^{l}$, M. I. Карстенс ${ }^{2}$, Т. Дж. Циклаурі ${ }^{1}$, Е. Е. Карстенс ${ }^{2}$

\section{ПОВЕДІНКОВЕ ТА ЕЛЕКТРОФІЗІОЛОГІЧНЕ ТЕСТУ- ВАННЯ ТЕРМАЛЬНОЇ ТА МЕХАНІЧНОЇ МОДУЛЯЦІЇ БОЛЮ З ВИКОРИСТАННЯМ АГОНІСТІВ ТRР-КАНАЛІВ}

${ }^{1}$ Експериментальний біомедичний центр ім. І. Беріташвілі, Тбілісі (Грузія).

${ }^{2}$ Каліфорнійський університет, Девіс (США).

P е 3 ю м е

Канали транзієнтного рецепторного потенціалу (transient receptor potential channels, TRP) були відносно докладно вивчені протягом останніх п'яти років. Згідно з результатами сучасних досліджень у галузі болю існує сім'я канальних структур, що складається 3 шести видів термо-TRP-каналів (TRPA1, TRPM8, TRPV1, TRPV2, TRPV3 та TRPV4). Такі канали виявляють чутливість до збільшення або зменшення температури, а також до хімічних речовин, котрі викликають відповідне відчуття гарячого або холодного. До подібних агентів належать ментол, коричний альдегід, гінгерол, гірчична олія, капсаїцин, камфора, евгенол та ін. У нашому дослідженні ми використовували поведінкові та електрофізіологічні методи, щоб з'ясувати, чи впливають гірчична олія (аліл ізотіоціанат, АІТЦ) та капсаїцин на чутливість самців щурів до термальних, нешкідливих холодових або механічних стимулів. Унілатеральні внутрішньопідошовні ін'єкції АІТЦ та капсаїцину зумовлювали істотні скорочення латентного періоду відсмикування іпсілатеральної кінцівки від шкідливого гарячого стимулу, тобто теплову гіпералгезію. Ці агенти також істотно зменшували пороги відсмикування кінцівки при дії механічного стимулу на ін'єковану кінцівку, тобто викликали механічну алодінію. Білатеральні внутрішньопідошовні ін'ієкції АІТЦ приводили до двофазного впливу на реакцію уникання від холоду (тест термальної преференції). АІТЦ у низькій концентрації (5\%) не змінював холодового уникання порівняно 3 контролем, тоді як у вищих концентраціях (10 та 15 \%) істотно пригнічував реакцію уникання на холод, тобто індукував холодову гіпоалгезію. Капсаїцин діяв майже таким самим чином. Ці результати вказують на те, що TRPA1-канали безперечно залучені у больові реакції і що АІТЦ (агоніст TRPA1) посилює чутливість до теплового болю (можливо, через непряме модулювання TRPV1-каналів, котрі коекспресуються у ноцицепторах з TRPA1s). У електрофізіологічних експериментах нейронні відповіді на електричні та ступінчасті механічні та шкідливі термальні стимули тестувалися перед шкірною аплікацією АІТЦ та після такої дії. Повторна аплікація АІТЦ спочатку збільшувала частоту розрядів спінальних нейронів 3 широким динамічним діапазоном; це спричиняло швидку десенситизацію, котра утримувалася після аплікації АІТЦ, застосованої за 30 хв. Відповіді на шкідливу термальну (але не на механічну) стимуляцію істотно збільшувалися незалежно від того, чи активувався нейрон АІТЦ безпосередньо. Ці результати вказують на те, що АІТЦ спричинює периферичну сенситизацію теплових рецепторів. У цілому наші результати говорять на користь ролі термосенситивних TRPA1- та TRPV1-каналів у больовій модуляції та свідчать про те, що дані термо-ТRР-канали $\epsilon$ перспективними мішенями для розвитку нової групи аналгетиків.

\section{REFERENCES}

1. A. I. Basbaum, D. M. Bautista, G. Scherrer, and D. Julius, "Cellular and molecular mechanisms of pain," Cell, 139, 267284 (2009).

2. K. A. Gerhold and D. M. Bautista, "Molecular and cellular mechanisms of trigeminal chemosensation," Ann. N. Y. Acad. Sci., 1170, 184-189 (2009).

3. C. Belmonte and F. Viana, "Molecular and cellular limits to somatosensory specificity," Mol. Pain, 4, article number 14 (2008); doi:10.1186/1744-8069-4-14.

4. E. Carstens, A. Klein, M. G. Tsagareli, et al., "Effects of thermo-sensitive transient receptor potential (TRP) channel agonists on the neural coding of touch, temperature and pain sensation," in: Proceedings of the 9th International Conference "Gagra Talks," Tbilisi (2010), pp. 267-280.

5. M. G. Tsagareli, "Behavioral testing of the effects of thermosensitive TRP channel agonists on touch, temperature, and pain sensations," Neurophysiology, 43, No. 4, 309-320 (2011).

6. M. G. Tsagareli, N. Tsiklauri, K. L. Zanotto, et al., "Behavioral evidence of heat hyperalgesia and mechanical allodynia induced by intradermal cinnamaldehyde in rats," Neurosci. Lett., 473, 233-236 (2010).

7. A. H. Klein, M. Iodi Carstens, M. G. Tsagareli, et al., "Topical application of 1-menthol induces heat analgesia, mechanical allodynia, and a biphasic effect on cold sensitivity in rats," Behav. Brain Res., 212, 179-186 (2010).

8. D. M. Bautista, S.-E. Jordt, T. Nikai, et al., "TRPA1 mediates 
the inflammatory actions of environmental irritants and proalgesic agents," Cell, 124, 1269-1282 (2006).

9. S.-E. Jordt, D. M. Bautista, H.-H. Chuang, et al., "Mustard oils and cannabinoids excite sensory nerve fibers through the TRP channel ANKTM1," Nature, 427, 260-265 (2004).

10. B. Namer, F. Seifert, H.O. Handwerker, and C. Maihöfner, "TRPA1 and TRPM8 activation in humans: effects of cinnamaldehyde and menthol," NeuroReport, 16, 955-959 (2005).

11. G. Brand and L. Jacquot, "Sensitization and desensitization to allyl isothiocyanate (mustard oil) in the nasal cavity," Chem. Senses, 27, 593-598 (2002).

12. C. T. Simons, M. I. Carstens, and E. Carstens, "Oral irritation by mustard oil: self-desensitization and cross-desensitization with capsaicin," Chem. Senses, 28, 459-465 (2003).

13. K. C. Albin, M. I. Carstens, and E. Carstens, "Modulation of oral heat and cold pain by irritant chemicals," Chem. Senses, 33, 3-15 (2008).

14. E. Carstens and T. Mitsuyo, "Neural correlates of oral irritation by mustard oil and other pungent chemicals: a hot topic," Chem. Senses, Suppl. 1, i203-i204 (2005).

15. C. T. Simons, S. Sudo, M. Sudo, and E. Carstens, "Mustard oil has differential effects on the response of trigeminal caudalis neurons to heat and acidity," Pain, 110, 64-71 (2004).

16. K. L. Zanotto, A. W. Merrill, M. Iodi Carstens, and E. Carstens, "Neurons in superficial trigeminal subnucleus caudalis responsive to oral cooling by menthol and other irritant stimuli," J. Neurophysiol., 97, 966-978 (2007)

17. M. J. Caterina, M. A. Schumacher, M. Tominaga, et al., "The capsaicin receptor: a heat-activated ion channel in the pain pathway," Nature, 389, 816-824 (1997).

18. M. J. Caterina, A. Leffler, A. B. Malmberg, et al., "Impaired nociception and pain sensation in mice lacking the capsaicin receptor," Science, 288, 306-313 (2000).

19. M. Caterina, "Transient receptor potential ion channels as participants in thermosensation and thermoregulation," $\mathrm{Am}$. J. Physiol. Regul. Integr. Comp. Physiol., 292, R64-R76 (2007).

20. M. Bandell, G. M. Story, S. W. Hwang, et al., "Noxious cold ion channel TRPA 1 is activated by pungent compounds and bradykinin," Neuron, 41, 849-857 (2004).

21. J. M. Bráz and A. I. Basbaum, "Differential ATF3 expression in dorsal root ganglion neurons reveals the profile of primary afferents engaged by diverse noxious chemical stimuli," Pain, 150, No. 2, 290-301 (2010).

22. K. Y. Kwan, A. J. Allchorne, M. A. Vollrath, et al., "TRPA1 contributes to cold, mechanical, and chemical nociception but is not essential for hair-cell transduction," Neuron, 50, 277289 (2006).

23. L. J. Macpherson, B. H. Geierstanger, V. Viswanath, et al., "The pungency of garlic: activation of TRPA1 and TRPV1 in response to allicin," Curr. Biol., 15, 929-934 (2005).

24. K. Kobayashi, T. Fukuoka, K. Obata, et al., "Distinct expression of TRPM8, TRPA1, and TRPV1 mRNAs in rat primary afferent neurons with A-delta/C-fibers and colocalization with TRK receptors," J. Comp. Neurol., 493, 596-606 (2005).

25. T. Sugiura, M. Tominaga, H. Katsuya, and K. Mizumura, "Bradykinin lowers the threshold temperature for heat activation of vanilloid receptor $1, " J$. Neurophysiol., 88, 544548 (2002).
26. H.-H. Chuang, E. D. Prescott, H. Kong, et al., "Bradykinin and nerve growth factor release the capsaicin receptor from PtdIns(4,5)P2-mediated inhibition," Nature, 411, 957-962 (2001).

27. M. Trevisani, J. Siemens, S. Materazzi, et al., "4-Hydroxynonenal, an endogenous aldehyde, causes pain and neurogenic inflammation through activation of the irritant receptor TRPA1," Proc. Natl. Acad. Sci. USA, 104, No. 3, 13519-13524 (2007).

28. M. Koltzenburg, L. E. Lundberg, and H. E. Torebjork, "Dynamic and static components of mechanical hyperalgesia in human hairy skin," Pain, 51, 207-219 (1992).

29. A. Pertovaara and A. Koivisto, "TRPA1 ion channel in the spinal dorsal horn as a therapeutic target in central pain hypersensitivity and cutaneous neurogenic inflammation," Eur. J. Pharmacol., 666, 1-4 (2011).

30. H. Wei, M. Karimaa, T. Korjamo, et al., "Transient receptor potential ankyrin 1 ion channel contributes to guarding pain and mechanical hypersensitivity in a rat model of postoperative pain," Anesthesiology, 117, No. 1, 137-148 (2012).

31. H. Wei, A. Koivisto, M. Saarnilehto, et al., "Spinal transient receptor potential ankyrin 1 channel contributes to central pain hypersensitivity in various pathophysiological conditions in the rat," Pain, 152, 582-591 (2011).

32. S. Eid, E. Crown, E. Moore, et al., "HC-030031, a TRPA1 selective antagonist, attenuates inflammatory- and neuropathyinduced mechanical hypersensitivity," Mol. Pain, 4, 48-57 (2008)

33. P. Kerstein, D. del Camino, M. Moran, et al., "Pharmacological blockade of TRPA1 inhibits mechanical firing in nociceptors," Mol. Pain, 5, 19-31 (2009)

34. Y. Karashima, K. Talavera, W. Everaerts, et al., "TRPA1 acts as a cold sensor in vitro and in vivo," Proc. Natl. Acad. Sci. USA, 106, 1273-1278 (2009).

35. G. M. Story, A. M. Peier, A. J. Reeve, et al., "ANKTM1, a TRP-like channel expressed in nociceptive neurons, is activated by cold temperatures," Cell, 112, 819-829 (2003).

36. R. H. LaMotte, L. E. Lundberg, and H. E. Torebjork, "Pain, hyperalgesia and activity in nociceptive $\mathrm{C}$ units in humans after intradermal injection of capsaicin," J. Physiol., 448, 749764 (1992).

37. R. H. LaMotte, C. N. Shain, D. A. Simone, and E. F. Tsai, "Neurogenic hyperalgesia: psychophysical studies of underlying mechanisms," J. Neurophysiol., 66, 190-211 (1991).

38. H. E. Torebjork, L. E. Lundberg, and R. H. LaMotte, "Central changes in processing of mechanoreceptive input in capsaicin-induced secondary hyperalgesia in humans," $J$. Physiol., 448, 765-780 (1992).

39. E. Carstens, K. C. Albin, C. T. Simons, and M. I. Carstens, "Time course of self-desensitization of oral irritation by nicotine and capsaicin," Chem. Senses, 32, 811-816 (2007).

40. N. B. Ruparel, A. M. Patwardhan, A. N. Akopian, and K. M. Hargreaves, "Homologous and heterologous desensitization of capsaicin and mustard oil responses utilize different cellular pathways in nociceptors," Pain, 35, 271-279 (2008).

41. A. W. Merrill, J. M. Cuellar, J. H. Judd, et al., "Effects of TRPA 1 agonists mustard oil and cinnamaldehyde on lumbar spinal wide-dynamic range neuronal responses to innocuous and noxious cutaneous stimuli in rats," J. Neurophysiol., 99, 415-425 (2008). 